\title{
The Activity of Pyramid Schemes in Albania (1992 - 1997) and the Effects of Their Decline
}

\author{
Adelina Nexhipi PhD Cand. \\ ., University of Tirana, Faculty of History and Philology
}

Erjon Nexhipi PhD Cand.

University of Korca, Economy Faculty

\begin{abstract}
Political transition in Albania during the last 10 years of the past century brought about the collapse of communist system and opened the way to democratic developments for the country. The transition towards democracy was accompanied with new social, economic and political events which brought with them a lot of issues however. The transition from a centralized economy to free market economy progressed rapidly, but these processes did not comply with the right banking legislation. The National Bank of Albania dominated the banking market;. This was one of the main reasons for the establishment and expansion of pyramid schemes in Albania. They operated largely from 1992 - 1997. This descriptive - analytical study reviews the activity of pyramid schemes in Albania, their expansion dimensions; the survey analyzes the reasons for their expansion, the attitude of the Government toward the event and the causes of their decline. In conducting this study, reports and analyses from the World Bank, International Monetary Fund, Bank of Albania, several media reports and studies from national and international researchers have been taken into consideration. Through this study we aim to explore the reasons for pyramid schemes' expansion and the mutual relation between the financial and political crisis in Albania.
\end{abstract}

Keywords: Albania, pyramid schemes, financial crisis, political crisis. Field of study: multidisciplinary topics

\section{Introduction}

During the dictatorship period, Albania had implemented the policy of economic centralization, which was a planned and closed economy without any private property element, in villages as well as in towns. Competition was forbidden and was viewed as imperialist and bourgeois tendency. Foreign investments and credits from abroad were also forbidden by the Albanian Constitution in 1976. Communist regime prioritized the heavy industry, neglecting thus the development of infrastructure and communication network which affected the economic progress of the country. Albania didn't undertake any important economic or political reform which would animate the economy such as decision-making decentralization, increase of the market role or democratization. The model implemented during 45 years relied on consistent application of Marxist ideology and Stalinist practices. In the 80 s, the policy of being relied upon their own forces and complete isolation, caused an apparent degradation of economy, decline of payment balance, failure of foreign currency resources, lack of consumer goods, etc.

The end of communist regime and the beginning of the transition period found a very problematic Albania. The country was financially bankrupt, depending on humanitarian donations, and the economy was collapsed. Professor Valentina Duka, having analyzed the economic situation in Albania during 1990, claims: "....looked like the [country] was just emerged from a war. Practically everything should start over... the Albanian economy which was built to be commanded, had no command. Since planning was not in use anymore and market was not established yet, the Albanian economy was immersed in chaos and anarchy."

1 Dh Kule, "Macroeconomic consolidation: Achievements and challenges", December 6, 2001, p. 1 [online] available at: http://www.bankofalbania.org/ 
The transition process towards the democratic system and the market economy is painful as nature, but in Albania's case it was made up of pressures. Albanian governments had to face a lot of major problems and overcome many challenges. The economic growth by steady steps is one of the major challenges, argues Professor Dhori Kule in his paper "Macroeconomic consolidation: Achievements and challenges". He discusses that "Transition of a country from a centralized economy to market economy involves many problems, where facing inflation and providing sustainable rates for economic growth are chief conditions for a successful transition."1

1992 was the year when implementation of stabilization program, price liberalization, budget deficit balance, coercive monetary policies, liberalization of foreign trade, reforms in privatizing the social protection network, establishment of tax system and a legal framework for market economy started applying in Albania. Immediate measures were undertaken such as: no subsidiary on agricultural products, a minimal limit on nominal salaries was established, a new customs system was established and non-rentable enterprises were closed.

In the framework of transformations, an important and inevitable process was the privatization process. This process was done rapidly, beginning with small and medium enterprises and agriculture as well. The level of reform development in economy and massive privatization process were not accompanied by privatizations in banking system though. Law $\mathrm{Nr}$. 8033, dated 16.11.1995, on "Transformation of commercial banks in commercial associations and their allowance for privatization" was not applied in the due time. During 1996, as result of licensing, the Albanian banking system expanded. There were 8 banks operating in Albania as follows:

\section{Banks with state capital:}

National Commercial Bank

Agriculture Commercial Bank

Savings Bank

\section{Banks with common capital}

Italian-Albanian Bank

Islamic Albanian - Arab Bank

\section{Banks with private capital:}

Dardania Bank

\section{Banks with foreign private capital:}

Tirana Bank

\section{Banks with state foreign capital:}

National Bank of Greece

However, based on the annual report in 1996 of the Bank of Albania, commercial banks with state capital dominated the banking market; over $90 \%$ of the total banking activity was operated from them. ${ }^{2}$.

Based on law on Bank of Albania in 1992, the banking system in Albania was divided into 2 levels. Bank of Albania was a first-level bank, whereas the National Commercial Bank, Agriculture Commercial Bank and the Savings Bank were secondlevel banks. Economic transformations, the reforms and the new legislation apparently produced their advantages, Albania achieved impressive results. GDP was no longer declining, market provided a variety of products, currency value was stable, deficit was reduced and inflation as well, trade increased especially retailing, and unemployment was reduced too. (Table 1) According to Bezemer "Following its profound economic reforms in 1992, the country had been celebrated in

\footnotetext{
1 Banka e Shqipwrisë, Raporti vjetor 1996, p. 50, [online] available at:: https://www.bankofalbania.org/web/Raporti_Vjetor_1996_2007_1.php)

$2 \mathrm{D}$ Bezemer, Post - socialist financial fragility: the case of Albania, p. 2, [online] available at::

https://www.researchgate.net/publication/5208271
} 
much of the literature on the economics of transition as the classic example of sound post-socialist economic policy in line with the 'Washington consensus'. By mid-1993, it could be claimed of Albania that is was the only country in Central and Eastern Europe that met every IMF-criterion."1 Main branches of economy were trade, construction, transport and mine industry. Apart from achievements, poverty was still high, and yet Albania was the poorest country in Europe.

Since 1991 there operated a number of pyramid schemes companies in Albania. They were well spread in the whole country and provided enormous interests on deposits, varying from $30 \%$ to $50 \%$. Poor Albanians, with low salaries and high unemployment, without other income sources and lacking information on private financial institutions, were tempted by high profit interests and fast enrichment. Also, people trusted the slogans and ads coming from these pyramid schemes in written and visual media of the time. Neither public institutions kept their distance from these companies, and nor did the opposition, which could make use of them to strike the government.

USA and IMF appealed to the Government in autumn 1996 to stop the activity of pyramid schemes and take control of their deposits, warning it of what could happen. The Government did not respond immediately, probably because Berisha did not want to cause problems and complaints ahead of local elections in October of the same year.

Expansion of pyramid schemes in Albania, was described by the distinguished newspaper "Daily Finance", as one of the world's major 10 financial scandals (ranking it at fifth place) ${ }^{2}$ which surpassed the sizes of any other world analogue phenomena in every aspect and duration, involving the population in the aftermath.

What were the factors affecting and assisting the establishment of pyramid schemes? What was the magnitude of their activity? What was the attitude of Albanian institutions and IMF towards them? What were the consequences of their decline for the country? These are some of the topics that will be discussed in this paper. The study relies on the official documents analysis from the Bank of Albania, the IMF and testimonies of those who lived the events and studies from home and foreign authors.

\section{What are the pyramid schemes?}

A pyramid scheme is a business model (not necessarily an investment) that involves promising investors or participants mainly for recruiting other people into the scheme. Pyramid schemes work on thw principle that money paid in by later investors is used to pay artificially high returns to earlier investors. Early investors are drawn in by advertising promising high interest rates, or huge capital gains after a short period. Most of the schemes have a gimmick, often based on some real or imagined market inefficiency or loophole in the law. News of the high returns spreads by word of mouth or advertizing and more people invest. Their payments are used to pay interest and if necessary principal to the early investors. More often, though, the early investors will reinvest their principal, and sometimes their interest in the hope of still higher gains.

Pyramid schemes typically go through the following stages:

- Initiation, when the first subscriptions or investments are handed over

- Validation, when large and easy rewards earned by initial members generate strong word-of-mouth publicity

- Expansion, when a large number of people join or massive investments are received, and

- Collapse, when defaults occur and promoters seek to abscond with invested money.

The IMF survey of 2009, IMF Advice Helps Fight Financial Fraud as Schemes Multiply, emphasized: "Controlling and closing down pyramids, and particularly Ponzi schemes, can be politically difficult-especially if politicians or other important people are subscribers to the scheme. Once they grow, the authorities may be increasingly reluctant to trigger their collapse"3.

\section{The dimension of the pyramid schemes activity in Albania}

\footnotetext{
1 B Lund, 10 financial scandals of all the time, Daily Finance, Apr 18th 2014, available [online] at: https://www.aol.com/article/finance/2014/04/18/top-10-financial-scandals/20871664/

2 IMF Survey: IMF Advice Helps Fight Financial Fraud as Schemes Multiply, p. 4, [online] available at::

http://www.imf.org/en/news/articles/2015/09/28/04/53/sopol021209a

3 D Bezemer, Post-Socialist Financial Fragility: The Case of Albania, p. 10
} 
Pyramid schemes started to operate in Albanian since 1991. The first to start with the deceiving borrowing activity was Hajdin Sejdia, an Albanian from Kosovo, serving as Prime minister's Fatos Nano adviser in 1991. He escaped from Albania with millions of dollars that acquired from Albanian citizens through fraud. His case was thought to be an isolated one, but from 1992 to 1997 other 24 borrowing companies were established and operating in Albania: Gjallica, VEFA, Populli, Demokracia Popullore-Xhaferri, Kamberi, Cenaj, Silva, Malvasia, Kambo, Grunjasi, Dypero, Bashkimi, Beno, Pogoni, B\&G, Kobuzi, Arkond, Adelin, A.Delon, Agi, M.Leka Company, Global Limited Co., Çashku, Sudja. The major ones were:

VEFA, established in October 1992. The President of the company was Vehbi Alimuçaj. The business activity started as a commercial company. Later on, he invested in supermarkets, restaurants, bitumen mine, built a mall, and established a TV station. It operated more than 200 businesses and employed 10,000 people. ${ }^{1}$ The auditors believe that VEFA took in at least $\$ 700$ million in deposits, and probably, over US\$1 billion. When it was taken over, liabilities, excluding some US $\$ 200$ million in accrued interests, amounted to US $\$ 250$ million, while its assets were generously estimated at US $\$ 300$ million. $^{2}$

Gjallica, started the activity as currency exchange in 1991. The President of the company was Shemsie Kadria settled in Vlora. Gjallica owned enterprises in trade, medicine and tourism, carried out some real investments, financing the construction of supermarkets, office complexes and gas stations. Gjallica was something of an elite company, with about 170.000 investors at its peak. ${ }^{3}$

Populli, with Bashkim Driza as president. Started its activity as a charitable foundation in early 1996. It attracted 400.000 investors. At the time of its collapse liabilities were over US $\$ 150$ million. ${ }^{4}$

Xhaferi, with Rrapush Xhaferin as president, introduced as charitable company, attracted about 1.500 .000 investors. At the time of its collapse liabilities were over US $\$ 300$ million. $^{5}$

Sude, established by Maksude Kasemi in 1993. Since then to 1996, she operated half legally. Liabilities variously estimated at US\$40-90 million. 6

These companies borrowed with interests varying from $10 \%-30 \%$ and $50 \%$ in 1996 for months. Some companies invested the money in different areas, on their behalf. Investments were mainly made in sectors like construction, trade, tourism, transport, fuel, etc, so as to show the creditors that it was a great profit opportunity. These companies were promoted as success stories in the Albanian business face; they employed tens of people, invested mainly on visible assets, were focused on advertising their activity, made many donations on art, culture and sports and supported the political campaigns in country. As far as their documentation chaos is concerned, it is difficult to understand whether these companies were able to pay - thus, their profit was higher than debts - or they were pyramid schemes since the very beginning. Other companies such as Sudja, Xhaferi or Populli, were authentic pyramid schemes; they had neither assets nor investments.

Tempted by high interest rates, Albanian people borrowed to these companies hoping for a fast increase of their incomes. They invested several times in some companies, making their investment on pyramid schemes "their favourite sport" argues Remzi Lani. Pyramid schemes in Albania represent a specific phenomenon as related to the size of popular involvement in them: almost as two third of population invested their money on pyramid schemes. At the time of the collapse of the schemes, they had more than 2 million depositors (out of a total population of 3,5 million). ${ }^{8}$ Different categories of people invested their incomes: emigrants, unemployed farmers, public employees, intellectuals, politicians and foreign diplomats.

\footnotetext{
${ }^{1}$ C Jarvis, The Rise and Fall of Albania's Pyramid Schemes, p. 14, [online] available at:: https://www.imf.org/external/pubs/ft/wp/1999/wp9998.pdf

2 ibid, p. 14

3 lbid, p. 14

4 Ibid, p.14

${ }^{5}$ Ibid, p 14

${ }^{6}$ R Lani, ALBANIA: IMF Warnings Of 'Pyramid' Fraud Fall On Poverty Dulled Ears, [online] available at: http://www.ipsnews.net/1996/11

${ }^{7}$ M Skreb, E Kraft, Financial crises in South East Europe causes, features and lessons learned, p 9, [online] available at:: https://www.researchgate.net/publication/254955151

${ }^{8} \mathrm{C}$ Elbirt, Albania under the shadow of the pyramids, [online] available at:: http://www.transgallaxys.com/ beo/mlm/albania_org.htm
} 
Being on top of their expansion during the second half of 1996, the amount of deposits in pyramid schemes was US\$ 1.2 billion, as half as the country's GDP. ${ }^{1}$

The borrowing companies operated in the whole country, but the largest number of deposits came from the southern part of Albania. this is because of the large number of emigrants and their remittances, and also because the southern part is neighbor to Greece and Italy, which opened the doors to contrabandists.

Such high involvement of people can be explained through some reasons:

Albanian people who grew up and were used to the commanded economy had no idea of how private financial institutions worked.

Those who understood the way of pyramid schemes operation, took the risk in multiplying their incomes, just like gambling;

People who were unemployed and had no incomes, those who had very low salaries believed that "the bank cheque" as promised was

appearing and it was their chance to achieve their "dream to become rich, producing money as if in a greenhouse". ${ }^{2}$

The huge publicity to the pyramid schemes in written media and TV served as assurance to people against any risks.

Non-response of state against the activity of these companies, made people believe they had the support of the government.

Carlos Elbirt, representative of the World Bank in Albania at that time, argues that "the public could not believe that a scheme involving every other Albanian family would not be guaranteed by the government. Moreover, pyramid managers were seen at official receptions, and they were interviewed daily by the government-controlled television stations"3. Bezemer expresses the same opinion: "the frequent appearance of pyramid managers and government officials side by side at public meetings and on television, and the association of pyramid managers with the Democratic Party lent state credibility to the schemes". ${ }^{4}$

\section{Causes for the expansion of pyramid schemes}

According to Bezemer, "Ponzi schemes and other financial-market aberrations in the region was no mere idiosyncrasy, but inadvertedly fostered by the combination of restrictive monetary policies, a lack of market regulation, large capital inflows, and weak governments". ${ }^{5}$

The large flourish of informal market in Albania was favored by a series of factors such as: economic environment in 199596, legal gap, lack of a consolidated formal market and its institutions, lack of economic culture.

Let us analyze below some of these factors:

Lack of structural reforms in banking sector, insufficiency of formal financial system.

All three state banks tried to keep higher interest rates than inflation rates in the mid $90 \mathrm{~s}$, but their issue was not the interest rates, but delays in transfers and other bank transactions. Lack of confidence at state banks made Albanian people to keep large amounts of cash and look for other investment alternatives, "in the absence of well-developed stock and real estate markets, this induced people and firms to revert to transactions on informal markets"6

\footnotetext{
${ }_{1}^{1}$ P Zogaj, Transition Institutions 1, (UET Press, Tirane: 2009) pg 235

${ }^{2}$ Carlos Elbirt, Albania under the shadow of the pyramids

${ }^{3}$ D Bezemer, Post-Socialist Financial Fragility: The Case of Albania, p. 11

${ }^{4} \mathrm{lbid}, \mathrm{pg} 4$

${ }^{5} \mathrm{lbid}, \mathrm{pg} 8$

${ }^{6}$ Banka e Shqipërisë, Raporti vjetor 1997, p. 7, [online] available at:

https://www.bankofalbania.org/web/Raporti_Vjetor_1997_2006_1.php
} 
The increasing number of bad credits forced banks to establish several criteria in allowing credits and put upper limits while allowing them. The number of loans (credits) from the state banks did not "satiate" the market demand for credit. Therefore, the private sector addressed to informal market in getting loans.

As far as shortcomings of formal financial market were concerned, the Report from the National Albanian Bank in 1997 pointed out:

Inability of the banking system to support the economy with investments. The cost for credits increased largely and the majority of allowed credits turned into non-payable credits. This caused problems for the crediting activity of state banks and brought considerable losses with it.

The relatively low weight of private banks in the Albanian banking system. These banks developed a limited activity concentrated mainly in the capital city. Main tendency of private banks was the intermediation in foreign currency activity.

Lack of an effective and regulated capital market. ${ }^{1}$

\section{Large amount of foreign currency in country}

Money which was provided through remittances, illegal traffics, savings from fixed incomes, while lacking other investment options, was invested on borrowing companies, which having promised high interest rates, introduced themselves as a better alternative for investment and profit. According to Preç Zogaj (representative of the opposition at that time): "people who were tired and losing hope, were more and more massively looking for salvation through borrowing lottery"2.

The weak legal systems, political interference in financial sector supervision, and inadequate coordination among supervisory institutions and governments.

In his analysis on the factors affecting the expansion of pyramid schemes, Chris Jarvis points out that after 1996 elections that were considered as manipulated, the power of government was fragile and its willingness to make important decisions was limited, even those decisions against pyramid schemes. In supporting this opinion, Marko Skreb and Evan Kraft argue that "in Albania during the rise of the pyramid schemes, no one wanted to deal with them. For quite some time they were no one's problem"3

\section{Collapse of pyramid schemes}

"Sude", one of the pyramid schemes with the highest interest rates, suspended the payment of installments for its depositors in November and in January $15^{\text {th }}$ she declared that the company bankrupt admitting to be a pyramid scheme. Other firms followed bankrupt afterwards. Presidents of pyramid schemes first "Populli" and "Xhaferri" companies were sent in prison being charged with fraud. The Government took under its control their deposits and declared to distribute them to depositors.

Decline of Gjallica Company, "the elite company" made people aware that all companies were pyramid schemes. Their ending was inevitable; it was just a matter of time.

According to analysts of the Albanian pyramid schemes the main events contributed to the collapse of pyramid schemes in late 1996 and early 1997:

The first was the lifting of sanctions on FR Yugoslavia at the end of 1995. This meant that profitable smuggling activities financed by money from the pyramid schemes began to dry up.

Second, the upcoming parliamentary elections created uncertainty whether the ruling Democratic Party (which actively supported the schemes) would win.

Third, the normal dynamics of pyramid schemes: they always collapse sooner or later. Further, increased competition (new entry) led to the increase of monthly interest rates to $6-10 \%$ per month in the first half of 1996.

\footnotetext{
${ }^{1}$ P Zogaj, Intuicionet e tranzicionit 1, p. 274

2 M Skreb, E Kraft, Financial crises in South East Europe causes, features and lessons learned, p. 24

${ }^{3} \mathrm{C}$ Jarvis, The Rise and Fall of Albania's Pyramid Schemes, p. 7
} 


\section{Attitude of the Albanian Government towards the pyramid schemes}

Since the beginning of the transition period in Albania, informal monetary exchange market and money borrowing deposits flourished in Albania and generally was tolerated by the state authorities. Both authorities and foreign observers, including the IMF, considered the activity of these companies as an opportunity for economic growth, filling the gaps of the banking system. ${ }^{1}$

As mentioned above, some of these companies were registered as legal businesses and some other as foundations, but they were not licensed to run banking activity. However, the existing legal basis was very poor to go against the pyramid schemes, especially on application level. These companies were licensed businesses and operated under the Civil Code, which allowed borrowings from companies. However, state didn't audit them and these companies did not appear to pay the tax on profit. ${ }^{2}$

In February 22 ${ }^{\text {nd }}, 1996$, The Parliament passed the Law "On Banking system in the Republic of Albania" which provided that bank one the one to have the right for accepting family deposits, saving accounts, and deposits with 12 months maturity or less. Through this law, the Governor of the Bank of Albania announced that the borrowing companies' activities were illegal, but the General Prosecutor declared that law was not applied on these companies. The Governor of the Bank of Albania during 1996 informed several times the president and the prime minister about the consequences of these companies' activities, still lacking of an institutional response.

For political reasons, the government of the Democratic Party and its allies evaded informing the Albanian people about the possible consequences of its "investment" activities on the one hand, and on the other, permitted the "companies" to carry on operating. Regarding the rest of the political forces of the country, they too share part of the responsibility because they were unable to make the ordinary citizen aware of the risks involved with respect to the "Pyramides". ${ }^{3}$

The Government did not take measures nor informed the people about the risks, even after the IMF and the Bank of Albania's warnings about the true nature of borrowing companies. Researchers give a few reasons about why this happened:

According to Miranda Vickers, President Berisha did not want people discontent ahead of the local elections in October $1996^{4}$

According to Bezemer, the Government and the Democratic Party made profits from the pyramid schemes "The evidence in the empirical section clearly points to government involvement and officials' profiting from Ponzi growth. In all probability they recognized the destructive impact of Ponzi schemes; but equally probably they had every private disincentive to discourage further growth." ${ }^{5}$

According to Preç Zogaj, the activities of pyramid schemes indirectly were the Government's allies, "The Government, being unable to fulfill the people's demands for jobs and minimal salaries, was satisfied that most of them found the solution by themselves"6

Faced accusations against the opposition, Preç Zogaj lists the reasons why the political opposition had an unclear attitude on pyramid schemes:

It was not sure that by striking them, the pyramid schemes would close. If that was to happen, the opposition would lose the support of the creditor voters.

Pyramids were a kind of mystery even for the opposition members.

Pyramids were considered the fate of the party in power; they were the disgrace of it.

\footnotetext{
1 lbid, p. 10

${ }^{2} \mathrm{~N}$ Ziogas, Albanian Crisis, p. 3, [online] Available at: http://www.hri.org/MFA/thesis/spring97/albanian_crisis.html

3 J. Pettifer, M. Vickers, Çështja shqiptare, riformësimi i Ballkanit, Bota shqiptare, Tirane, 2007, p.129

${ }^{4}$ D Bezemer, Post-Socialist Financial Fragility: The Case of Albania, p. 24

5 P Zogaj, Intuicionet e tranzicionit 1, UET Press, Tiranë, 2009, p. 274

6 lbid, pg 275
} 
Some of the opposition members, as citizens, had deposited money in these companies, or were employed in them, therefore were not interested in going against them. ${ }^{1}$

As far as this indifferent attitude of governing institutions is concerned, people blamed the Government after the pyramid schemes collapsed. The fact is supported by the Bank of Albania as well in its 1998 newsletter "it is already known that economic regulatory policies are written and applied from the authorities and we are right to say that nothing is done in this aspect."

The Minister of Finances, Ridvan Bode, after the yearly meeting with representatives from the World Bank and IMF in Washington, October 1996, warned people about the risk their deposits were running. The warning did not appeal to Albanian people who continued to deposit their money in the borrowing companies intensely. The Government institutions reacted only when the pyramid schemes gave the first signs of collapse.

In January 26th, 1997 banks accounts for companies Xhaferri and Populli were frozen.

By its own initiative, the Bank of Albania decided to limit daily withdrawals by 30 million Leke.

After Gjallica collapsed, the borrowing activities of all companies were blocked, their accounts were frozen and law on auditing them financially passed.

The late reaction of the authorities was not only caused by an inadequate legal framework but broadly speaking was a problem of governance i.e. of crisis management. The authorities reacted slowly and weakly. Linkages with highest levels of the government and corruption postponed adequate reaction for some time. This delay not only allowed the schemes to grow but also delayed the seizure of remaining assets, which facilitated asset stripping. ${ }^{3}$

\section{Attitude of IMF toward pyramids}

In warning about the financial development in country, World Bank in 1994 and IMF in 1995, considered the borrowing companies which invested on their accounts and did not issue credit as an informal crediting market, without realizing that their activity was a pyramid.

During 1996, the World Bank and FMN warned continuously the risk from pyramid schemes, but the Albanian Government turned a deaf ear. A strong warning was made from an expert team from IMF in Albania in August. After their visit in Albania, the IMF mission sent a letter to the Albanian President warning him about the risk of pyramid schemes and the need to undertake immediate measures.

Same warnings came from the World Bank mission during their visit to Albania in September. In October in Washington, during the yearly meeting, IMF and the World Bank repeated their warnings to the Minister of Finances, Mr. Z. Ridvan Bode.

In November 19th, another IMF mission in Albania, through a press conference informed the public opinion about the pyramid schemes asking the Government to investigate the companies.

Nevertheless, the IMF warnings, although it assisted continuously the Albanian institutions, came late as well. This is because of several objective reasons, according to Jarvis:

It was difficult to distinguish between the legitimate informal market, which was and continues to be a benefit to Albania, and the schemes that were set up as investment funds.

The pyramid schemes were basically criminal organizations, and the IMF is not in the business of investigating criminal organizations.

\footnotetext{
1 Banka e Shqipërisè, Buletini Ekonomik, Vellimi 1, Numër 3, 1998, p. 3

2 M Skreb, E Kraft, Financial crises in South East Europe causes, features and lessons learned, p. 10

3 IMF Survey, Volume 28, Nr 21, November 1999, pp. 15 - 16, [online] available at: https://www. imf,org
} 
The IMF was hesitant to call publicly for an investigation and for a freezing of assets. It has a responsibility to try to head off major financial crime with a macroeconomic impact, but it also has a responsibility not to recklessly blacken the reputation of companies that may be legitimate. ${ }^{1}$

Besides these factors, Bezemer adds that IMF monitoring on the economic progress is made only based on macroeconomic indicators data, which in Albania's case were stable. It may have been the particular way of monitoring the economy, with excessive attention to macro-economic (particularly monetary) indicators, which misled observers. It was shown for the Albanian case how Ponzi growth may leave macro-economic figures unaffected. In this respect, Albania is again extreme but not unique. If economic performance is monitored exclusively through observation of the macroeconomic variables, the development of fragile financial markets may go unnoticed. ${ }^{2}$

After the crisis emerged from the collapse of pyramid schemes, IMF offered its assistance to the Albanian government in order to overcome the financial effects caused by the pyramid schemes activity.

\section{Effects of the activity and collapse of pyramid schemes}

Activities of pyramid schemes brought many consequences both when they were operating and after they collapsed.

The effects of the activity of pyramid schemes:

On social aspect, they fed passivity, lack of willingness to work, reduction of workforce. While average salaries did not exceed $\$ 70$ a month, people were attracted to higher incomes the pyramid schemes provided ${ }^{3}$

On economic aspect, they set back investments on economy, high interests of rental companies made people to want to deposit their savings and not invest them. "Ponzi schemes immobilize money that could have been used (more) productively. In the extreme, capital inflows in a Ponzi-dominated economy have no effect on welfare, but merely increase the amount of money in circulation, driving up nominal wages and prices at constant real incomes"4. Whereas, the investing activity of these companies was almost nil, something that paralyzed the economy entirely, reducing its productive activity.

On banking aspect, they destroyed the savings. Banking situation became worse on one hand, because of deposit decline and "bank resources were on the minimal and lowest levels, since banks should fulfill the considerable demands of people for cash"s. On the other hand, the pyramid activity interfered with the Bank of Albania's inspection of monetary situation, allowing a lot of money to move outside banking channels.

Because of the high amount of money in circulation, the price of consumer goods increased although there was no increase of macro-economic indicators. A 12-month increase of Consumer Price Index, reached at 17.4, according to the Bank of Albania. ${ }^{6}$

Collapse of pyramid schemes affected worse the Albanian economy and society:

According the Bank of Albania Report, the effect pyramid schemes on economic aspect was:

They set back the production activity since the beginning of the year until it ceased during 1997. General insecurity and downfalls brought about the production set-back, decline of investments and commerce, etc.

They brought about a considerable increase of prices. From $17.4 \%$ during 1996, the level of prices went up more than twice reaching at $42.1 \%$.

Budget deficit increased, mainly during the first half of the year. Because of the lack of Cash liquidity in second-level banks and inactivity of state finances, the deficit was financed entirely by the Bank of Albania. Whereas, during the second half of the year, since customs and other financial links were put into function, the level of incomes increased. The policy

\footnotetext{
${ }^{1}$ D Bezemer, Post-Socialist Financial Fragility: The Case of Albania, p. 28

2 lbid, pg 11

3 lbid, pg 14

${ }^{4}$ Banka e Shqiperise, Raporti vjetor 1997, p.11

5 Banka e Shqiperise, Raporti vjetor 1996, p. 9

${ }^{6}$ Banka e Shqiperise,Raporti vjetor 199, p. 7 - 8
} 
applied by the Bank of Albania related to interest levels, the short-term especially, increased the deposits in Leke in public banks which were the main funders for the budget deficit.

They deepened the trade deficit and the current deficit. Total lack of exports during the first six months of 1997, reduced the foreign exchange resources. On the other hand, national currency was depreciated further at $44.6 \%$.

People's loss of confidence at formal financial market and distrust in investing their money in this market. During the first half of 1997. Number of current deposits in banks declined both in Leke and foreign currency. As a result of such withdrawal there is an increase of money outside banks by 29.8 billion Leke. This fact showed a considerable lack of liquidity in commercial banks.. ${ }^{1}$ (Table 2)

In social aspect, after the pyramid schemes collapsed, chaos and anarchy took hold of the country until the first half of 1997.

In January 1997 people's revolts began in the country, who blamed the government for losing their money. Firstly, they began in Lushnja, Berat, Vlora and later in all the Southern part of Albania, whose inhabitants had lost big sums of money in the pyramid schemes. Revolts became violent and violence started to increase in a scary way. The Southern part of Albania was out of state control. The state started to "break down" within few days. The revolted people set the buildings of state institutions on fire; they blocked national roads, opened the food depots.

Meanwhile, apathy dominated in Tirana. The popularity of the government had decreased. Government's institutions were not able to take actions that could calm people's anger. The forces of the Albanian Intelligence Service (SHIK) were used at the beginning of the protests to preserve order.

The opposition tried to use people's anger for its political purposes. The opposing press was full of bombastic titles that legitimized the people's anger and stimulated the anti-Berisha movement. Many representatives of the opposing parties participated in the civic protests in the South of the country. The government accused the opposition of stimulating violence and of supporting the criminal acts of the protesters. On 30 January, the opposing parties together with the association of the former political prisoners created the Forum for Democracy, an anti-governmental alliance that tried to channel the movement into institutional ways. But in fact, now three poles were created: the government, which wanted to keep the power by all means; the opposition, which wanted to take the power by using all means, and the crowd, which wanted to use its anger and did not care about the fate of the political elite in Tirana.

The revolted persons in the South of the country opened the ammunitions warehouses and were armed "to protect themselves from the forces of Berisha, who were sent to kill them", as they said in interviews given for foreign correspondents. With the opening of prisons, armed dangerous criminals moved freely in Albania. Crime increase at a scary level; violence became uncontrollable, fear for life became the biggest anxiety for simple citizens, economic activity was paralyzed. The number of murders increased every day. Miranda Vickers talks about more than $1700{ }^{2}$ cases of murder during the revolts of 1997; meanwhile, there were no official sources for the number of murders. Chaos and anarchy dominated in the whole country.

"Salvation Committees" were created in the Southern part of Albania with civic representatives and often from the group of "the strong ones" (groups that carried out illegal and criminal activities, even before the beginning of revolts), with the purpose to control the situation in the absence of the local governmental institutions. The people's revolt did not have any specific action philosophy, but its only purpose was to remove Berisha from power. This was made clear in their appeals, in which they compared Berisha with moneylenders, they accused him of the violence that was used against them and they used offending words against him.

President Berisha and the government made the preservation of order the first priority, but when this became impossible, Prime Minister Aleksandër Meksi asked in parliament to declare the state of emergency. In his speech in parliament, the Prime Minister said that considering the actual situation and the fact that the state cannot control the situation with peaceful means, this is the only way to guarantee the lives of citizens and their economic and social activity. The emergency state was declared on 2 March. The law on the emergency state was criticized by the international factor. On the other hand,

\footnotetext{
1 J Pettifer, M Vickers, Çështja Shqiptare, riformësimi i Ballkanit, p. 129

2 B Fino, Humnere ‘97, Edisud, Tiranë, 2007, p. 35
} 
the law gave the government the right to rule with decrees and to use the military against its opponents. For this reason, active representatives of the opposition felt threatened by the actions that could be taken against them. After that, collaboration between the crowd and the political opposition intensified.

In this political and social state of confusion, a day later, on 3 March, Berisha was confirmed President from the Parliament. This increased people's anger even more, and they wanted the resignation of Berisha. Opposition forces asked the President to reach a political agreement. A meeting was held between the President and representatives of the Forum for Democracy on 6 March, but it failed. The agreement could be reached few days later only with the intervention of the international community.

The international factor started worrying more and more about the events in Albania and for the direction they were taking. International institutions called upon the Albanian political class for caution and cooperation in order to find a solution to the benefit of Albania and Albanians. When they say that their warnings were falling on deaf ears, the OSCE decided to send its representative Franz Vranitzky in Tirana to mediate talks between the political forces in the country. It was precisely with his mediation that the Albanian political forces managed to sign an agreement on 9 March. Based on the agreement reached, the government of Aleksander Meksi resigned and a coalition government was created with a broad political spectrum, which would govern the country until the formation of the new government after the early parliamentary elections on 29 June of that year.

Bashkim Fino was elected Prime Minister of the National Reconciliation government. The main task of the government was to preserve peace and order, and to hold elections. In Albania's actual situation these two tasks seemed an "impossible mission". In his book "97 abyss", Prime Minister Bashkim Fino writes about his first days as Prime Minister: "When I think about those times, I can say - a mediator between the angel and the devil."

Although the situation continued to remain tense and chaotic, some improvements were noticed after the creation of the government. The Salvation Committees began to recognize the authority of the government. They began a campaign to start discussions with the population, and they asked the assistance of the international community, which sent Alba Mission in Albania. This program was run by Italians, who would help to restore order and distribute humanitarian aid to the population.

The organization of elections was considered an opportunity to pull the country out of the crisis, but everyone was aware that holding free and democratic elections at a time when the population was armed would be difficult. The election campaign was organized in a hostile environment. Both sides accused each other of the crisis created in the country. The Election Day was generally calm, and considering the present situation, and the level of participation was high. Nevertheless, the level of tension was high and incidents were numerous.

Despite the problems, OSCE-ODIHR assessed elections as acceptable. The election result was a severe shock to the Democratic Party, which faced its biggest loss. Socialists came to power and formed a government headed by Fatos Nano. The government had to restore the state, the confidence of the people; it had to establish peace and order, disarm the population; in other words, it had to heal the financial, political, social and institutional wounds of the crisis

\section{Conclusions}

Companies which resulted in pyramid schemes were established and expanded in Albania during 1991 - 1997. They are a special case in Europe because of their expanding size; the amount of deposits in pyramid schemes was US $\$ 1,2$ billion and number of depositors was 2 million. Factors which affected their establishment and expansion are both economic and political. Important factors are: poor public institutions, lack of structural reforms in banking system, insufficiency of a formal financial system.

Since archives lack documentation, it is difficult today to certify the state involvement in the activity of pyramid schemes; yet it is undeniable the fact that the indifferent attitude of state towards the pyramid schemes encouraged their expansion.

\footnotetext{
1 Data was provided from the World Bank database, [online] available at:: http://dataworldbank.org/indicator/NY.GDP.PCAP.CD/countries
} 
Government did not take legal measures in time so as to protect the citizens from financial fraud. Undoubtedly, it was the job of state institutions.

Activity of pyramid schemes affected the economic and social life of the country, but their collapse brought about fatal consequences in economy, politics and society; they set back production activity, increased the budget deficit, deepened trade and current deficit, affected people's confidence at formal financial market, brought about the social anarchy in 1997, Government's failure, paralyzed the public institutions and early elections.

Table 1. Macroeconomic indicators 1991 - $1996^{1}$

\begin{tabular}{|l|l|l|l|l|l|l|}
\hline Year & 1991 & 1992 & 1993 & 1994 & 1995 & 1996 \\
\hline Incomes for capita & 346 & 217 & 381 & 625 & 772 & 968 \\
\hline GDP increase(in \%) & -29.6 & -7.2 & 9.6 & - & 13.3 & 9.1 \\
\hline Inflation & 38.6 & 249.7 & 114.8 & 38.4 & 5.6 & 28.4 \\
\hline
\end{tabular}

Table 2. Macro-economic indicators 1997(annual average in \%)2

\begin{tabular}{|l|l|}
\hline Indicators & Amount \\
\hline Real increase of GDP(in \%) & -7.0 \\
\hline Current account deficit (\% GDP) & -12.1 \\
\hline Fiscal deficit (\% GDP) & -12.9 \\
\hline Increase of GDP (in \%) & -10.2 \\
\hline Inflation & 13.9 \\
\hline
\end{tabular}

\section{References}

[1] Banka e Shqipwrisw. (1996). Raporti vjetor. [online] available at: https://www.bankofalbania.org/web/Raporti_Vjetor_1996_2007_1.php

[2] Banka e Shqipwrisw. (1997). Raporti vjetor. [online] available at:

[3] https://www.bankofalbania.org/web/Raporti_Vjetor_1997_2006_1.php

[4] Banka e Shqipërisë. (1998). Buletini Ekonomik. 1 (3)

[5] Bezemer, D. (2001). Post - socialist financial fragility: the case of Albania. [online] available at: https://www.researchgate.net/publication/5208271

[6] Duka, V. (2008). Historia e Shqipërisë 1912- 2000. Tiranë: Kristalina-KH

[7] Elbirt, C. (1997). Albania under the shadow of the pyramids. [online] available at:

[8] http://www.transgallaxys.com/ beo/mlm/albania_org.htm

[9] Fino, B. (2007). Humnerë '97. Tiranë: Edisud

[10] IMF Survey. (1999) 28 (21) [online] available at:: https://www.imf.org

${ }^{1}$ Banka e Shqiperise, Raporti vjetor 1997, p. 7 - 8

2 The expectation model that is described here are not as obstructive as accounted by (Elton, Gruber, Brown, \& Goetzmann, 2009) and (Chordia \& Swaminathan, 2000) that found risk premia constant at zero. 
[11] IMF Survey. (2009). IMF Advice Helps Fight Financial Fraud as Schemes Multiply. [online] available at: http://www.imf.org/en/news/articles/2015/09/28/04/53/sopol021209

[12] Jarvis, C. (1999) The Rise and Fall of Albania's Pyramid Schemes. [online] available at: https://www.imf.org/external/pubs/tt/wp/1999/wp9998.pdf

[13] Kule, Dh. (2001). "Macroeconomic consolidation: Achievements and challenges". [online] available at: http://www.bankofalbania.org/

[14] Lani, R. (1996) ALBANIA: IMF Warnings Of 'Pyramid' Fraud Fall On Poverty Dulled Ears. [online] available at: http://www.ipsnews.net/1996/11

[15] Lund, B. (2014) 10 financial scandals of all the time, Daily Finance. Apr 18th 2014. [online] available at: https://www.aol.com/article/finance/2014/04/18/top-10-financial-scandals

[16] New York Times. (1997). Revolt Spreads to Albanian Capital's Outskirts. [online] available at:: http://www.nytimes.com

[17] Pettifer, J. \& Vickers, M. (2007). Çështja shqiptare, riformësimi i Ballkanit. Tirane: Bota shqiptare

[18] Skreb, M. \& Kraft, E. (2015). Financial crises in South East Europe causes, features and lessons learne. [online] available at: $h$ htps://www.researchgate.net/publication/254955151

[19] Zogaj, P. (2009). Intuicionet e tranzicionit 1. Tirane: UET Press

[20] Ziogas, N. (1997). Albanian Crisis. [online] available at:

[21] http://www.hri.org/MFA/thesis/spring97/albanian_crisis.html 